\title{
The Osmotically Regulated proU Locus of Salmonella typhimurium Encodes a Periplasmic Betaine-binding Protein
}

\author{
By CHRISTOPHER F. HIGGINS, ${ }^{1}{ }^{*}$ LESLEY SUTHERLAND, ${ }^{1}$ \\ JOHN CAIRNEY ${ }^{1}$ AND IAN R. BOOTH ${ }^{2}$ \\ ${ }^{1}$ Molecular Genetics Laboratory, Department of Biochemistry, University of Dundee, \\ Dundee DD1 4HN, UK \\ 2 Department of Microbiology, Marischal College, University of Aberdeen, \\ Aberdeen $A B 91 A S, U K$
}

(Received 16 June 1986)

\begin{abstract}
The proU locus of Salmonella typhimurium encodes an osmotically induced betaine transport system. We have identified a $31 \mathrm{kDa}$ periplasmic protein, encoded by proU, whose synthesis is induced by osmotic stress. A specific betaine-binding activity with a $K_{\mathrm{D}}$ of about $1 \mu \mathrm{M}$ is also present in the periplasm of osmotically induced cells. This activity is absent in those proU mutants which lack the $31 \mathrm{kDa}$ periplasmic protein. Thus, ProU is a periplasmic bindingprotein-dependent transport system.
\end{abstract}

\section{INTRODUCTION}

Betaine plays an important role as an osmoprotectant in many plant, animal and bacterial species (Le Rudulier \& Valentine, 1982; Le Rudulier et al., 1984; Yancey et al., 1982). In Escherichia coli and Salmonella typhimurium, betaine stimulates growth at high osmolarity, serving to restore turgor and to protect intracellular enzymes against the adverse effects of high cytoplasmic ionic strength (Cairney et al., 1985a, b; Perroud \& Le Rudulier, 1985). Two genetically distinct transport systems serve to mediate betaine uptake. The proP gene encodes a low-affinity betaine transport system which also has some affinity for proline (Cairney et al., $1985 a$ ). The proU locus encodes a high-affinity betaine transport system with a $K_{\mathrm{t}}$ of $1.3 \mu \mathrm{M}$ (Cairney et al., 1985b). Betaine uptake via the ProU transport system is regulated at two levels. Expression of the proU locus is induced by osmotic stress (Cairney et al., 1985b; Dunlap \& Csonka, 1985; Gowrishankar, 1985) in direct response to osmotically induced increases in intracellular $\mathrm{K}^{+}$concentrations (Sutherland et al., 1986). Once expression of proU is fully induced, the activity of the ProU transport system is also regulated in response to osmotic stress (Cairney et al., 1985 b). Because of its importance for growth at high osmolarity, and because of these unusual regulatory properties, we have set out to characterize the ProU transport system.

Two principal classes of bacterial transport system can be distinguished by their organization and the mechanism of energy-coupling to transport (Berger \& Heppel, 1974). Membrane-bound transport systems, typified by the lactose permease, are unicomponent and are energized by ion gradients. In contrast, binding-protein-dependent systems are multicomponent and are believed to be energized by the direct hydrolysis of ATP or a related nucleotide (Ames \& Higgins, 1983; Higgins et al., 1985; Ames, 1986). Binding-protein-dependent transport systems require the function of a specific substrate-binding protein located in the periplasm. These proteins exhibit high affinity for their specific substances which is reflected in the low $K_{\mathrm{t}}$ for transport when assayed in whole cells. In this paper we show that ProU is a binding-protein-dependent transport system and that the proU locus encodes a $31 \mathrm{kDa}$ periplasmic betaine-binding protein. 


\section{METHODS}

Bacteria. The two S. typhimurium strains used in this study were the wild-type LT2 (A) and its derivative CH946 [proU1702:: $\left.\mathrm{Mu} \mathrm{d1}-8\left(\mathrm{Ap}^{\mathrm{r}}, l a c\right)\right]$. The construction of $\mathrm{CH} 946$ was described by Cairney $e$ t al. $(1985 b)$.

Pulse-labelling proteins. Cells were grown aerobically at $30^{\circ} \mathrm{C}$ in M63 medium (Miller, 1972) containing $0.4 \%$ glucose as carbon source and each of the protein amino acids (except methionine) at $40 \mu \mathrm{g} \mathrm{ml}^{-1}$. When appropriate, cells in mid-exponential growth were osmotically shocked by adding $\mathrm{NaCl}$ to a final concentration of $0.3 \mathrm{M}$ and grown for a further $45 \mathrm{~min}$ before labelling. Samples $(1 \mathrm{ml})$ of cells were pulsed for $1 \mathrm{~min}$ with $\left[{ }^{35}\right.$ S]methionine [1.3 $\mathrm{Ci} \mathrm{mol}^{-1}\left(48 \cdot 1 \mathrm{GBq} \mathrm{mol}{ }^{-1}\right) ; 2 \mu \mathrm{Ci}(74 \mathrm{kBq})$; Amersham] followed by a 1 min "chase' with $100 \mu \mathrm{g}$ unlabelled methionine $\mathrm{ml}^{-1}$. Total protein extracts of the labelled cells were prepared by rapidly sedimenting the cells by centrifugation, resuspending them in $200 \mu$ l of Laemmli sample buffer (Laemmli, 1970) and boiling for $5 \mathrm{~min}$. Periplasmic fractions were isolated from the labelled cells by cold osmotic shock as described previously (Higgins \& Hardie, 1983). Proteins were separated by SDS-PAGE (Laemmli, 1970; Ames, 1974) and detected by autoradiography after drying the gel.

Betaine-binding measurements. Large-scale preparations of periplasmic proteins for binding assays were obtained by cold osmotic shock from 1 litre of cells grown to saturation in LB medium (Hiles \& Higgins, 1986). These preparations were dialysed extensively against $10 \mathrm{mM}-\mathrm{Tris} / \mathrm{HCl}(\mathrm{pH} \mathrm{7.2)}$, freeze dried and resuspended in Tris/ $\mathrm{HCl}\left(\mathrm{pH} \mathrm{7.2)}\right.$ to a final protein concentration of $10-15 \mathrm{mg} \mathrm{ml}^{-1}$. Betaine-binding assays were done by the filter-binding procedure (Dahl \& Manson, 1985). Samples (20 $\mu \mathrm{l}, 200-300 \mu \mathrm{g}$ protein) of periplasmic shock fluid were incubated for $2 \mathrm{~min}$ with the appropriate amount of $\left[{ }^{14} \mathrm{C}\right]$ betaine $\left[0.1 \mu \mathrm{Ci}(3.7 \mathrm{kBq}) ; 7.4 \mathrm{Ci} \mathrm{mol}^{-1}\right.$ $(273.8 \mathrm{GBq})$; Amersham] after which time $500 \mu \mathrm{l}$ of ice-cold saturated ammonium sulphate was added and the mix immediately passed through a $0.45 \mu \mathrm{m}$ nitrocellulose filter (Schleicher and Schuell). The filters were washed three times with $3 \mathrm{ml}$ of ice-cold saturated ammonium sulphate and the radioactivity retained by the wet filters measured by scintillation counting. Protein concentrations were determined by the method of Bradford (1976) using bovine serum albumin as a standard.

\section{RESULTS AND DISCUSSION}

\section{Identification of an osmotically induced periplasmic protein}

The proU locus encodes a high-affinity betaine transport system which plays an important role in osmoregulation (Cairney et al., 1985b). Expression of proU is osmotically induced. However, both genetic (Cairney et al., 1985 b) and biochemical (Clark \& Parker, 1984) data indicate that very few other genes are similarly induced. In order to identify any protein(s) encoded by proU, cells of LT2 (proU ${ }^{+}$) and $\mathrm{CH} 946$ ( proU) were pulse-labelled with ${ }^{35}$ S $]$ methionine either before or after osmotic shock. Fig. 1 shows a $12 \%(\mathrm{w} / \mathrm{v})$ SDS-polyacrylamide gel of the labelled proteins in whole cell extracts. It is clear that the expression of very few proteins is altered significantly by osmotic shock. Only two proteins, labelled A and B in Fig. 1, were reproducibly found to be regulated by osmolarity. Neither of these proteins was absent from $\mathrm{CH} 946$ (Fig. 1) or from a variety of other independently isolated proU mutants (data not shown). Protein A has a molecular mass of $36 \mathrm{kDa}$ and is only expressed in cells grown in media of low osmolarity. The use of appropriate mutants showed that this protein is not the osmotically regulated $\mathrm{OmpF}$ porin (Hall \& Silhavy, 1981) (data not shown). Protein A is not periplasmic (see below) and its function remains to be determined. Protein $B$ has a molecular mass of $21 \mathrm{kDa}$ and its synthesis is induced by osmotic shock. This protein has the same molecular mass as the $\mathrm{KdpC}$ subunit of the $\mathrm{Kdp}$ potassium transport system which is known to be osmotically induced (Laimins et al., 1981; Hesse et al., 1984). However, as $k d p$ mutants have not been isolated in $S$. typhimurium, it is not yet possible to determine rigorously whether or not protein $\mathrm{B}$ is a component of $\mathrm{Kdp}$.

Because any periplasmic protein encoded by proU might not be detectable amongst total cellular proteins, periplasmic fractions from pulse-labelled cells were prepared and separated by SDS-PAGE (Fig. 2). An osmotically induced protein of $31 \mathrm{kDa}$, which is masked by other proteins in total cell extracts, can be identified in these periplasmic fractions. This protein is absent from the periplasm of $\mathrm{CH} 946$ (Fig. 2) and from a number of other independently derived proU mutants (data not shown). Thus, proU directs the synthesis of a $31 \mathrm{kDa}$ periplasmic 


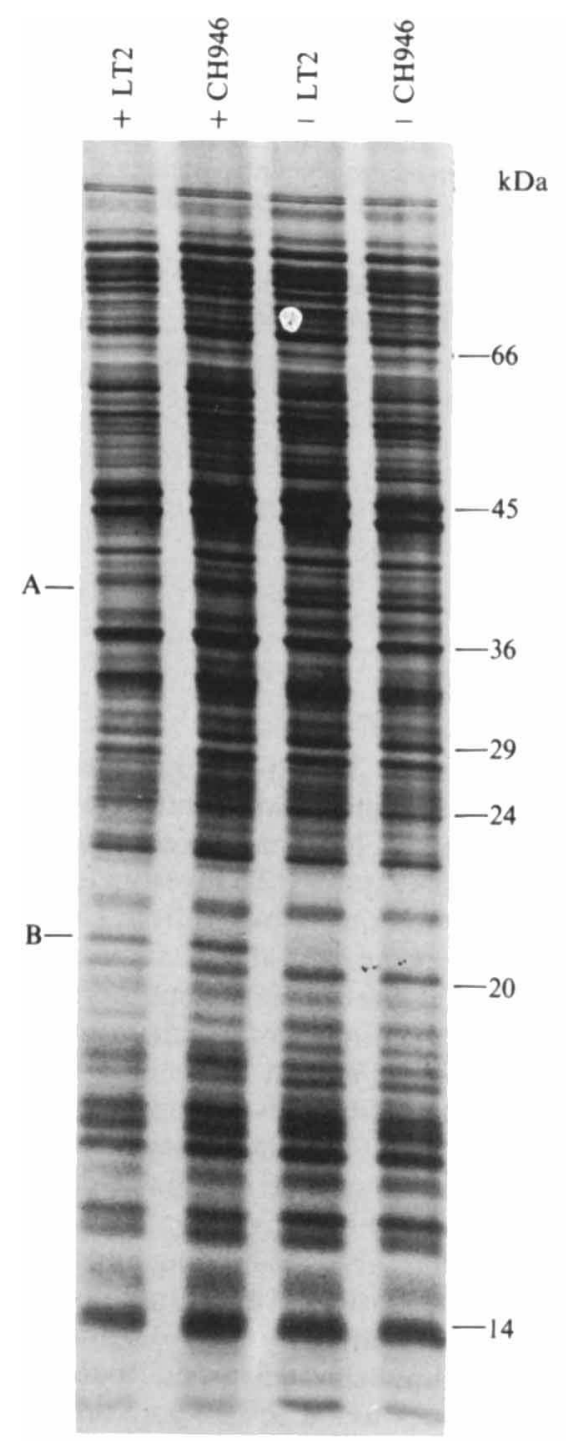

Fig. 1

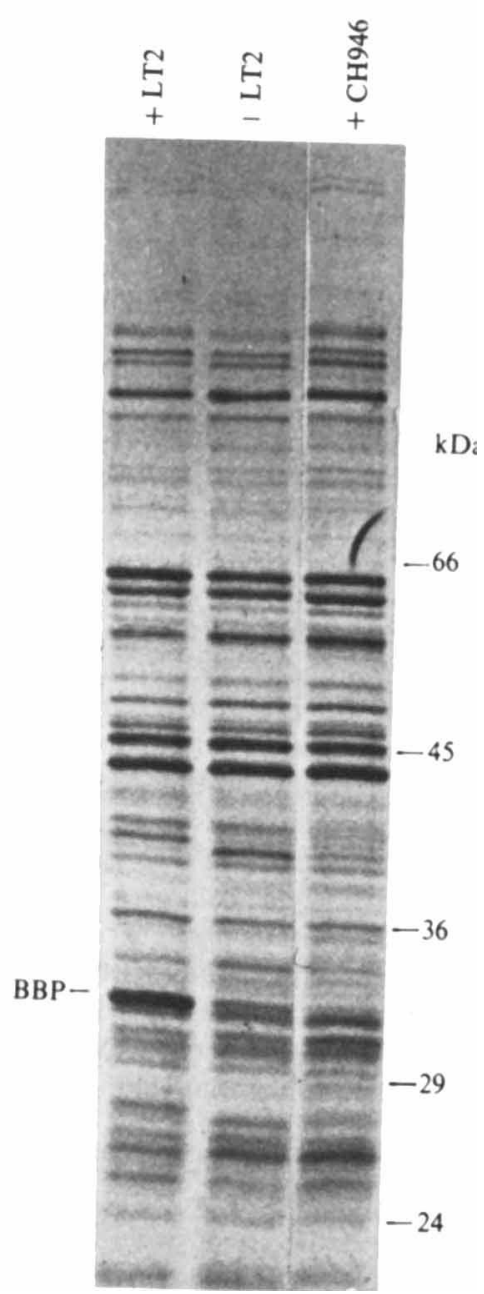

Fig. 2

Fig. 1. Osmotically induced proteins. Cellular proteins were pulse-labelled with $\left[{ }^{35} S\right]$ methionine, either before $(-)$ or after $(+)$ osmotic shock, and separated on a $12 \%(\mathrm{w} / \mathrm{v})$ SDS-polyacrylamide gel. Strain LT2 is wild-type; $\mathrm{CH} 946$ is a proU derivative. Proteins A and B are discussed in the text. The mobility of molecular mass markers is indicated.

Fig. 2. Osmotically induced periplasmic proteins. Periplasmic proteins were isolated from cells pulselabelled with $\left[{ }^{35}\right.$ S]methionine before $(-)$ or after $(+)$ osmotic shock and separated on an $8 \%(w / v)$ SDSpolyacrylamide gel. Strain LT2 is the wild-type; $\mathrm{CH} 946$ is a proU derivative. The betaine-binding protein (BBP) is indicated, as is the mobility of molecular mass markers.

protein. Although it still remains a formal possibility that the proU locus encodes a regulatory component, rather than the $31 \mathrm{kDa}$ protein itself, this seems highly unlikely in view of the fact that transcription of proU is so tightly regulated (regulatory genes are not normally subject to such stringent regulation) and because of the finding that all mutants defective in the ProU transport system map to this single locus (Cairney et al., 1985b; Sutherland et al., 1986). 


\title{
Table 1. Betaine-binding activities of periplasmic fractions
}

\begin{abstract}
Cells were grown in LB (low osmolarity) or LB containing $0.3 \mathrm{M}-\mathrm{NaCl}$ (high osmolarity). Binding assays were done in $10 \mathrm{~mm}$ - Tris $/ \mathrm{HCl}(\mathrm{pH} \mathrm{7.2)}$ with $0.3 \mathrm{M}-\mathrm{NaCl}$ or $0.44 \mathrm{M}$-sucrose added as indicated. Each measurement is the mean of three separate determinations carried out on independent preparations of periplasmic proteins. The range of values obtained was less than $10 \%$ of the average. Binding was assayed at saturating betaine concentrations $(20 \mu \mathrm{M})$.
\end{abstract}

$\begin{array}{lccc}\text { Strain } & \begin{array}{c}\text { Osmolarity of } \\ \text { growth medium }\end{array} & \begin{array}{c}\text { Addition to } \\ \text { assay }\end{array} & \begin{array}{c}\text { Betaine bound } \\ \text { [pmol (mg protein })^{-1} \text { ] }\end{array} \\ \text { LT2 } & \text { Low } & - & 39 \\ \text { LT2 } & \text { Low } & \mathrm{NaCl}(0 \cdot 3 \mathrm{M}) & 28 \\ \text { LT2 } & \text { High } & - & 486 \\ \text { LT2 } & \text { High } & \mathrm{NaCl}(0 \cdot 3 \mathrm{M}) & 511 \\ \text { LT2 } & \text { High } & \text { Sucrose }(0 \cdot 44 \mathrm{M}) & 451 \\ \text { CH946 } & \text { Low } & - & 11 \\ \text { CH946 } & \text { High } & - & 32 \\ \text { CH946 } & \text { High } & \mathrm{NaCl}(0 \cdot 3 \mathrm{M}) & 21\end{array}$

\section{Betaine-binding activity}

The periplasmic components of transport systems function as the initial, high-affinity substrate-binding receptor (Ames \& Higgins, 1983). Because proU mutants were both defective in transport and in the synthesis of a $31 \mathrm{kDa}$ periplasmic protein, it seemed likely that the $31 \mathrm{kDa}$ protein would be found to be a component of the transport system. To investigate this possibility, betaine-binding activity was assayed in periplasmic fractions isolated from LT2 or CH946 which had been grown at either low or at high osmolarity. Table 1 shows that periplasmic betaine-binding activity is absent from cells grown at low osmolarity but is present when wild-type cells are grown at high osmolarity. This is entirely consistent with the observation that proU expression and the ProU betaine transport system are only induced during growth at high osmolarity. However, betaine-binding activity was absent from the periplasmic fractions of $\mathrm{CH} 946$, even when grown at high osmolarity. This clearly demonstrates that ProU is a periplasmic binding-protein-dependent transport system and, in addition, strongly implies that the $31 \mathrm{kDa}$ periplasmic protein is the betaine-binding component.

Further support for this view comes from measurement of the substrate-binding affinity of this protein for betaine. Betaine-binding activity at different substrate concentrations was assayed in periplasmic fractions isolated from LT2 grown at high osmolarity (Fig. 3). Although binding could not be accurately measured at betaine concentrations below $0.5 \mu \mathrm{M}$, due to the low specific activity of the substrate, the $K_{\mathrm{D}}$ for betaine binding was found to be approximately $1.0 \mu \mathrm{M}$. This is in very good agreement with the $K_{\mathrm{t}}$ for ProU-dependent betaine transport which has previously been measured as $1.3 \mu \mathrm{M}$ (Cairney et al., 1985b).

Assuming that one molecule of protein binds one molecule of betaine, as is the case for other periplasmic binding proteins, it can be calculated from the data in Table 1 that the betainebinding protein comprises $1.3 \%$ of the total periplasmic protein. While this figure might seem rather low when compared with the amount of the $31 \mathrm{kDa}$ protein seen in pulse-labelling experiments (Fig. 2), it must be remembered that binding activity was measured in cells grown to steady-state in high osmolarity medium, rather than immediately after osmotic shock, which is when pulse-labelling was done and when pro $U$ expression is greatest relative to that of other proteins.

The demonstration that ProU is a binding-protein-dependent transport system has a number of important implications for the mechanisms, regulation and physiological function of this transport system. The finding is compatible with the high affinity of this transport system for its substrate $\left(K_{\mathrm{D}} 1.3 \mu \mathrm{M}\right)$ and with its ability to accumulate betaine against large concentration gradients (Cairney et al., 1985 b). These are features generally associated with binding-proteindependent transport systems (Ames \& Higgins, 1983). All other binding-protein-dependent transport systems have, in addition to the periplasmic substrate-binding component, several 


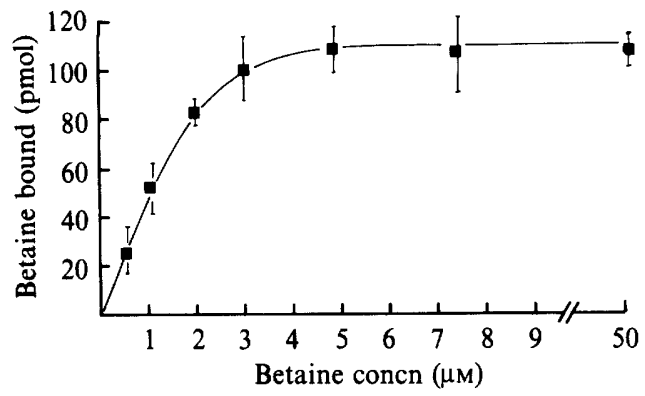

Fig. 3. Betaine-binding activity in the periplasm. Betaine-binding by periplasmic fractions isolated from $\mathrm{LT} 2$ grown at high osmolarity $(\mathrm{LB}+0.3 \mathrm{M}-\mathrm{NaCl})$ was assayed at various betaine concentrations. Each point is a mean of five independent determinations. The data are expressed as the amount of betaine bound per assay mix $(260 \mu \mathrm{g}$ protein).

(normally three) membrane-associated components (Ames \& Higgins, 1983; Ames, 1986). It therefore seems likely that the proU locus is an operon consisting of several genes. If, as for other transport systems, the membrane components of ProU are very much less abundant than the periplasmic components, this would explain why they have not been detected as osmotically induced proteins.

In addition to transcriptional regulation of proU expression, we have previously shown that activity of the ProU transport system is modulated by the osmolarity of the medium. Even when the proU locus is fully induced, ProU-dependent betaine transport can only be detected when assayed in medium of high osmolarity. A possible role for the betaine-binding protein in this regulation was investigated by raising the osmolarity of the binding assay mix by the addition of $0.3 \mathrm{M}-\mathrm{NaCl}$ or $0.44 \mathrm{M}$-sucrose. Betaine-binding was found to be identical whether or not the assay was done at high osmolarity (Table 1). It is also interesting to note that the function of this binding protein is not inhibited by high ionic strength. These data show that the osmotic regulation of ProU activity is not simply a consequence of altered substrate binding by the periplasmic betaine-binding protein. Rather, osmotic regulation of transport activity must be achieved by modulation of the function of other, presumably membrane-bound, components of the transport system.

$N B$. Since submitting this paper we have learned that $E$. coli has a similar betaine-binding protein (E. Bremer, personal communication).

We are grateful to Cynthia Greenwood for technical assistance and to Hannes Brass for advice about the betaine-binding assays. This work was funded by an MRC grant to C.F.H. and I. R. B. C.F.H. is a Lister Institute Research Fellow.

\section{REFERENCES}

AMES, G. F.-L. (1974). Resolution of bacterial proteins by polyacrylamide gel electrophoresis on slabs. Journal of Biological Chemistry 249, 634-644.

AMES, G. F.-L. (1986). Bacterial periplasmic transport systems: structure, mechanism, and evolution. Annual Review of Biochemistry 55, 397-425.

AMES, G. F.-L. \& Higgins, C. F. (1983). Mechanisms, organization and evolution of periplasmic transport systems. Trends in Biochemical Science 8, 97-100.

Berger, E. A. \& HePpel, L. A. (1974). Different mechanisms of energy coupling for the shocksensitive and shock-resistant amino acid permeases of Escherichia coli. Journal of Biological Chemistry 249, 7747-7755.

BRADFORD, M. (1976). A rapid and sensitive method for the quantitation of microgram quantities of protein utilizing the principle of protein-dye binding. Analytical Biochemistry 72, 248-254.

CAIRney, J., Booth, I. R. \& Higgins, C. F. (1985a). Salmonella typhimurium proP gene encodes a transport system for the osmoprotectant betaine. Journal of Bacteriology 164, 1218-1223.

Cairney, J., Booth, I. R. \& Higgins, C. F. (1985b). Osmoregulation of gene expression in Salmonella typhimurium: proU encodes an osmotically induced betaine transport system. Journal of Bacteriology 164, 1224-1232.

Clark, D. \& Parker, J. (1984). Proteins induced by high osmotic pressure in Escherichia coli. FEMS Microbiology Letters 25, 81-83. 
DaHL, M. K. \& Manson, M. D. (1985). Interspecific reconstitution of maltose transport and chemotaxis in Escherichia coli with maltose-binding protein from various enteric bacteria. Journal of Bacteriology 164, 1051-1063.

DunlaP, V. J. \& Csonka, L. N. (1985). Osmotic regulation of L-proline transport in Salmonella typhimurium. Journal of Bacteriology 163, 296-304.

GoWRISHANKAR, J. (1985). Identification of osmoresponsive genes in Escherichia coli: evidence for participation of potassium and proline transport systems in osmoregulation. Journal of Bacteriology 164, 434-445.

Hall, M. N. \& Silhavy, T. J. (1981). The ompB locus and the regulation of the major outer membrane porin proteins of Escherichia coli K12. Journal of Molecular Biology 146, 23-43.

Hesse, J. E., Wieczorek, L., Altendorf, K., Reicin, A. S., Dorus, E. \& Epstein, W. (1984). Sequence homology between two membrane transport ATPases, the Kdp-ATPase of Escherichia coli and the $\mathrm{Ca}^{2+}$-ATPase of sarcoplasmic reticulum. Proceedings of the National Academy of Sciences of the United States of America 81, 4746-4750.

Higgins, C. F. \& Hardie, M. M. (1983). Periplasmic protein associated with the oligopeptide permeases of Salmonella typhimurium and Escherichia coli. Journal of Bacteriology 155, 1434-1438.

Higgins, C. F., Hiles, I. D., Whalley, K. \& JAMIESON, D. J. (1985). Nucleotide binding by membrane compounds of bacterial periplasmic binding protein-dependent transport systems. EMBO Journal 4, 1033-1040.
Hiles, I. D. \& Higgins, C. F. (1986). Peptide uptake by Salmonella typhimurium: the periplasmic oligopeptide-binding protein. European Journal of Biochemistry 158, 561-567.

LAEMMLI, U. K. (1970). Cleavage of structural proteins during the assembly of the head of bacteriophage T4. Nature, London 227, 680-685.

Laimins, L. A., Rhoads, D. B. \& Epstein, W. (1981). Osmotic control of $k d p$ operon expression in Escherichia coli. Proceedings of the National Academy of Sciences of the United States of America 78, 464-468.

Le Rudulier, D. \& Valentine, R. C. (1982). Genetic engineering in agriculture: osmoregulation. Trends in Biochemical Science 7, 431-433.

Le Rudulier, D., Strom, A. R., Dandekar, A. M., SMith, L. T. \& Valentine, R. C. (1984). Molecular biology of osmoregulation. Science 224, 1064-1068.

MilleR, J. H. (1972). Experiments in Molecular Genetics. Cold Spring Harbor New York: Cold Spring Harbor Laboratory.

Perroud, D. \& Le Rudulier, D. (1985). Glycine betaine transport in Escherichia coli: osmotic modulation. Journal of Bacteriology 161, 393-401.

Sutherland, L., CaIRney, J., Elmore, M. J., Booth, I. R. \& Higgins, C. F. (1986). Osmotic regulation of transcription: induction of the proU betaine transport locus is determined by the accumulation of intracellular potassium. Journal of Bacteriology 168 , 805-814.

Yancey, P. H., Clark, M. E., Hand, S. C., Bowlus, R. D. \& Somero, G. N. (1982). Living with water stress: evolution of osmolyte systems. Science 217, 1214-1222. 